\title{
Contemporary Latin American Cinema and Resistance to Neoliberalism: Mapping the Field
}

\section{Claudia Sandberg}

Buenos Aires, April 2017: On the opening night of the annual BAFICI film festival, hundreds of people flocked the entry of the Cine Gaumont. Rather than seeking entrance to the opening film, they gathered to protest against proposed cutback measures which threaten the existence of the Argentine state-owned production company, INCAA (Instituto Nacional de Cine y Artes Audiovisuales). Under the center-right government of President Mauricio Macri, a number of employees were dismissed and the budget for cultural activities was cut. Film productions are at risk of being terminated because promised grants are not being paid out or belatedly so (Fig. 1.1).

The deteriorating state of affairs in the Argentine cultural sector mirrors a situation familiar to filmmakers and film personnel in other Latin American countries, where the responsibility of the state yields to the interests of private business and ownership. This essay investigates the impact of neoliberalism on Latin America filmmaking from the

C. Sandberg $(\square)$

School of Languages and Linguistics, University of Melbourne,

Melbourne, VIC, Australia

(C) The Author(s) 2018

C. Sandberg and C. Rocha (eds.), Contemporary Latin American

Cinema, https://doi.org/10.1007/978-3-319-77010-9_1 


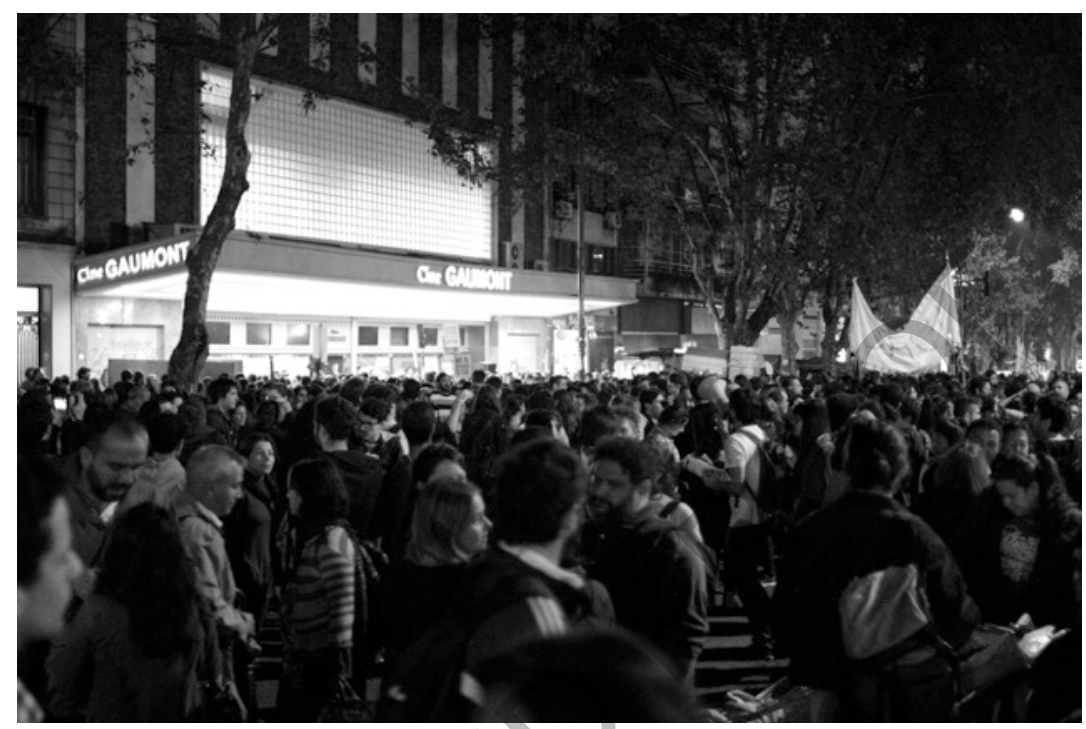

Fig. 1.1 Demonstration in front of the Cinema Gaumont in April 2017. (C Martín Turnes

1990s onwards, and serves as a framework for the case studies of the current volume. Contemporary Latin American Cinema: Resisting Neoliberalism? explores developments in filmmaking as a reflection of neoliberal political and economic measures and the neoliberal zeitgeist of our epoch. Many nations ushered in neoliberal policies during the 1990s, which centered on austerity measures prompting Latin American states to take a less prominent role in the funding of their national cinemas. This reduction in state funding had a profound impact on the Latin American cinematographic landscape. Other national and international funding sources had to pick up from the lack of state funding. New types of producers emerged, and novel patterns of film distribution, exhibition and consumption now shape and influence the Latin American film scape. With approaches to the subject such as film industry studies, reception analyses and close film readings, this book provides an overview of current filmmaking in Latin America with relation to neoliberalism tackling questions such as: Which impact did the privatizing of state-owned companies and dismantling of welfare systems have on funding opportunities, distribution and exhibition 
arrangements, narratives and aesthetics of Latin American film? In which ways does contemporary Latin American cinema resist, criticize but also benefit from neoliberal advancements? Have older filmmaking practices and traditions reemerged in new forms?

Before drawing attention to the ways in which neoliberal tendencies influenced the Latin American film industry, I provide a brief outline of the political events that have determined the present filmmaking conditions in Latin America. The above mentioned Argentine case is an example of a reemergence of neoliberalism after two decades of alternate political and economic avenues (2001-2015) that resisted the neoliberal paradigm in Latin America. A progressive cycle of governments starting with the election of Hugo Chávez as Venezuelan president in 1998. Left-center governments in Bolivia (Evo Morales), Argentina (Néstor Kirchner) and Brazil (Lula de Silva) had implemented economic strategies in their countries that scholars cautiously identified as post-neoliberal turn (Macdonald and Ruckert 2009, 2). These countries nationalized economic resources and implemented social reforms in order to offer lower social classes access to health, housing and education-effectively empowering poorer populations and bringing them into public visibility, eschewing international capital and reducing foreign investment (Grugel and Riggirozzi 2012). The government acted against fiscal deficits and promoted local and regional cooperation, even though it was never clear whether these "policy experiments" (Macdonald and Ruckert 2009, 2) established viable and sustainable alternatives or appealed to their populations (Roberts 2009, 1).

The optimism about such politics and economic strategies as alternatives to a free-market economy has faded in recent years. Center and center to right candidates have been selected in Argentina and Peru. The Brazilian president Dilma Rousseff, who had fostered nationalization measures, was impeached because of alleged misuse of public funds, and Evo Morales' government was defeated in the constitutional referendum to allow for the possibility of a fourth term.

Right-of-center governments in Paraguay, Honduras, Guatemala, Mexico and Colombia have been following strict neoliberal courses as political leaders believe that there is no other choice (Belém Lopes 2017). Barry Cannon notes that in these countries "neoliberalism is so deeply embedded in national power networks that alternative policy options are extremely difficult to implement without fierce elite 
resistance" (2016, 59). Among them, Chile has a specific relevance for the deployment of neoliberalism as governmentality. Chile has become shorthand for a radical free-market project, "to describe any logic of organization in which the market has a significant role, or in which individual economic incentives or an economic rationality prevail" (Venugopal 2015, 172). The concept of neoliberalism has been applied here as a set of economic measures that was hinged on repressive social and political measures of a violent regime. In the transformation from economic model to a worldwide hegemonic ideology, Chile set the parameters for a neoliberal model in Latin America as a contemporary form of neocolonial domination. This made Latin American countries increasingly dependent on powerful financial institutions such as the World Bank and the International Monetary Fund (Venugopal $2015,175-76)$. A model that became implemented often in times of crisis, neoliberalism protects the interest of higher classes and promotes an accumulation of wealth, while converting citizens into consumers. In light of the ongoing neoliberal transformation of the Latin American political, economic and social landscape, it is high time to examine how neoliberalism had pervaded its cinemas.

\section{The Latin American Film Industry in the Neoliberal ERA}

The free-market philosophy has long reached the cultural spheres and has been fully adopted in the global filmmaking sector. Frederic Jameson states that notions of culture and economy as independent spheres collapsed in postmodern times (1991, 4-5). The cultural sphere has become an integral part of commodity production, so much so that Jyotsna Kapur and Keith B. Wagner point out in the introduction to their book Neoliberalism and Global Cinemas that "the production of culture is, after war, the second most important sector of the neoliberal economy" $(2011,1)$. These shifts guide a policy making that supports, "a production of cinema as an industry and commodity" (Kapur and Wagner 2011, 3). Films have become consumable products, always linked to their capacity to make profits in local and global markets.

Despite the relevance and ubiquity of the matter, surprisingly few scholarly studies have investigated the nexus of contemporary cinema 
and neoliberalism. Kapur and Wagner's above-mentioned volume, conceived in the wake of the worldwide financial crisis of 2008 and drawing on Marxist critique of capitalism, was the first extensive Englishlanguage study of this subject. Its contributions deal with filmmaking in Hollywood, Latin America, Asia, Africa and Europe, geographically organized to underline unequal divisions of power and resources which have defined centers and peripheries of global capital. Another recent book-length publication, Ewa Mazierska and Lars Kristensen's Contemporary Cinema and Neoliberal Ideology, starts with the idea that "Cinema perfectly fits the idea of a neoliberal industry" (Mazierska $2018,10)$. This volume consists of studies of the political economy of film and covers topics such as filmmaking in post-socialist states, neoliberal genres, and matters of money, sex and consumption. While Kapur and Wagner's and Mazierska and Kristensen's books provide valuable insights into neoliberal transformations and their impact on cinemas worldwide, the relevance of our work rests on the particularities of the Latin American case. Contemporary Latin American Cinema. Resisting Neoliberalism? examines filmmaking as a reflection of the Latin American political, economic and social landscape and regimes of power that keep Latin American states dependent on European and American capitalism.

In recent years, Latin America has become an active player in the global film business. As Deborah Shaw notes, "directors and producers are more aware of the international market and have learned how to raise funds, create more audience-friendly films, and market their finished products" (Shaw 2007, 1). Produced with an eye on commercial success, films such as Amores perros (Alejandro González Iñárritu, 2000), Y tu mamá también (Alfonso Cuarón, 2001), Cidade de Deus (Fernando Meirelles, 2002), Whisky (Juan Pablo Rebella and Pablo Stoll, 2004), El laberinto del fauno (Guillermo del Toro, 2006), El secreto de sus ojos (Juan José Campanella, 2009) and No (Pablo Larraín, 2012) resonated with audiences worldwide, as they were "breaking away from art houses and into commercial multiplexes with great success and revenues" (Alvaray 2008, 49). The current volume aims to interrogate such accomplishments. At what costs did this "nouvelle vague of Latin American films" occur (Alvaray 2008, 51)? How many and what kind of films achieve a wide distribution, and against which other films do they compete? How many independent cinemas had to close to make room for yet another multiplex? 
From the early 1990s onwards, film became an integral part of efforts to create global media and telecommunication corporations and networks. Until then operating on regional and national levels and being at least partially protected by the state, the media landscape became one of private entities which developed an insatiable appetite for transnational expansion (McChesney 2001, 2). This on-going push to privatization and liberalization includes the film sector in Latin America and elsewhere.

Previously supported by direct forms of film financing through loans and subsidies, national deregulation dynamics and free-trade economic policies eliminated direct financial assistance. In Latin America, such economic policy changes led to drastic budget cuts in its biggest film nations; Brazil, Mexico and Argentina and devastated their local industries (Schroeder Rodriguez 2016, 245). The government of President Carlos Salinas de Gortaris in Mexico severely reduced the funding of IMCINCE (Instituto Mexicano de Cinematografia), which led to a dramatic drop of productions. In Brazil, President Collor de Mello dismantled the state agency EMBRAFILME. Even in Cuba, the cut off political and economic support from the Soviet Union ended funding for the state-operated film production company ICAIC (Instituto Cubano de Arte e Industria Cinematograficos) in 1989. The annual output there fell by $50 \%$ in the 1990 s, indicating that the changed political realities after the end of the Cold War in formerly socialist countries ushered in the rule of the market as anywhere else (Harvey 2008). Eventually, new state interventions revitalized local film markets and provoked an increase of filmmaking activities in a number of Latin American nations from the mid 1990s onwards. In Brazil, law 8313 and 8586, passed in 1991 and 1993, respectively, included a tax incentive system that stimulated private businesses, local media companies and foreign distributors to invest money in film making projects that promised good returns (Rêgo and Rocha 2011, 3). ${ }^{1}$ This assisted a wave of new productions, known as Retomada. In Argentina, the aforementioned cultural institute, INCAA, was founded in 1994 to stimulate national film and audiovisual arts through its competition schemes, credit lines, and a film channel that broadcasts national productions. Box-office revenues feed back into the system to finance directors and producers. In Peru (1994), Chile (2004), Colombia (2003) and Venezuela (1993, 2005), similar policies regulated quotas for national films, introduced taxes to support and fund indigenous filmmakers and granted tax exemptions to private investors. 
The neoliberal economic policies were simultaneously aided to protect the indigenous film industry and to maximize income from filmmaking activities by attracting foreign funds to flow into the Latin American domestic film market. This supported alliances and mergers with European, United States and Latin American companies, inevitably inviting globally operating and domineering media conglomerates into local markets. Unsurprisingly, US production companies and distribution networks could take most advantage of the deregulation measures. The Motion Picture Association of America (MPAA), which unites members of the major Hollywood studios, opened Latin American offices in the 1990s and set up coproduction and distribution networks that served as international platforms for US made film. From this point onwards, US-based exhibitors swept Latin America, attracting great audience numbers to and generating profits with their films (Rocha 2011, 18). The concentration of foreign capital in Latin America became particularly noticeable in the distribution and exhibition sector with the creation of multiplex models that are typically located in or near shopping malls (see also Chapter 10; Andrea Morán and Miguel Fernandez Labayen's study of the Argentine film industry). Cinemark and Cinépolis are among the cinema distribution and exhibition giants that buy and sell to each other and belong to even bigger media conglomerates in an ever-changing corporate media landscape. As of June 2011, Cinemark operates 1250 cineplexes in twelve Latin American countries: Argentina, Brazil, Chile, Colombia, Costa Rica, Ecuador, Guatemala, Honduras, México, Nicaragua, Panamá and El Salvador (Picciau 2011). These companies market foreign big-budget productions by projecting large numbers of copies in a large number of movie theatres. Evermore expensive productions need to recoup their investments internationally and on multiple platforms-cinema, television, videogames, cable and video-with the aim of generating multiple revenue streams (Simis 2015; Arantes 2017). This is being helped by the digital turn, i.e. the material migration of film to digital platforms and media, which the US majors use to their benefit. The streaming service Netflix is just one example of a digital business model that allows for individualized consumption of preselected video and film material. With almost limitless resources and ideas of how to sell old and new film content, the Hollywood industry keeps widening their leads into the Latin American market and creates entry barriers for smaller and independent regional companies. 
Massively funded US productions, an established distribution and exhibition network in Latin American film markets, and aggressive advertising campaigns restrict screen spaces for and the visibility of local productions. Ticket prices are often way beyond the spending power of local populations, making cinema-going unaffordable for lower social classes. Most multiplexes are situated in urban centers, which disadvantage those living farther away and in lesser-developed areas. The omnipotent presence of Hollywood film, as Néstor García Canclini notes, comes to determine popular audience tastes, if not promote cultural homogenization (García Canclini 1995, 10). Moreover, local film businesses emulate Hollywood production, distribution and marketing strategies. This further drives homogenizing tendencies. The Chilean production company Chilewood uses US-style marketing, including branding strategies and product placement within the mise-en-scène of their films, such as the Qué pena triology (Nicolás López, 2010-2012), which reflects, in the words of Jonathan Risner, "how the language of advertisement as a symptom of neoliberalism seeps into Chilean popular culture" (606). In a similar way, the Brazilian network Globo utilises Hollywood-style business practices, which has resulted in their products dominating the national film market.

In an effort to counter trends of monopolization and homogenization of Latin American film, initiatives at national, regional and pan-regional levels support and raise the visibility of Latin American film. Yet, these efforts are also part of the pervasive political, economic and social neoliberal system. A number of European-funded programs protect and create spaces for Latin American film at home and elsewhere. Author and filmmaker Antonio Skármeta wrote in 1997 that Europe could act as a fraternal partner for production and circulation of Latin American film, by utilizing affinitive networks and collaborations which were forged in the 1970s and 1980s, when in times of political repression many exiled Latin American filmmakers were closely associated to European film institutions and collaborated with colleagues in Spain, France or Germany. The climate and the conditions for such efforts have decisively changed. In an era of neoliberal ideology, the transition between "film as a national high cultural product in a rich subsidy system ... to film as popular entertainment circulating in a for-profit transnational network" (Halle 2010, 304), the interest for Latin American film is guided by market demands. Programs such as Programa Ibermedia, FondsSud and Ventana Sur are for-profit initiatives, founded to strengthen the presence of Latin 
American cinema on local and European film markets. Ventana Sur, for example, acts as a platform for a Latin American film market, a collaboration between the Argentine INCAA and the Marché du Film/Festival de Cannes. Created in November 2009 with the support of the European Commission, Ventana Sur is a meeting point for producers, distributors, Latin American film and film personnel. Established in 1998, Ibermedia promotes the distribution and exhibition of Ibero-American films, and offers exchanges and training of audiovisual personnel, a most important initiative in which currently nineteen Latin American states participate. Eighty percent of Ibermedia funding is spent on coproduction funds (Falicov 2013, 70). In particular smaller film industries benefit from this support. For example, Guatemala received over five hundred million dollars to help coproductions on their way. ${ }^{2}$ The Ibermedia coproduction agreement also helped increase the annual output of feature films in Peru (White 2015, 188-89). There are claims that Spain, as Ibermedia's biggest partner, has greater decision-making power and makes profits from film productions in countries with lower production costs. Nevertheless, Tamara Falicov points out that "while Spain has an obvious agenda for their heavy involvement with Ibermedia, it has proven to the most beneficial and successful film finance pool the region has currently" (2013, 84). Ibermedia contributes to safeguarding the existence of Latin American film, somewhat making up for five hundred years of colonial history and economic exploitation.

Film festivals have come to be of vital importance in the global film network, because they are an exhibition platform and marketplace alike. Latin American film festivals, such as Havana or Viña del Mar, with a rich and vibrant history of promoting political and experimental film, compete against a plethora of new ones. Not able to evade pressures to make ends meet financially and satisfy sponsors, investors and audiences, their political and socio-critical profiles have transformed into a branding strategy. As cultural venues with market-oriented agendas, a number of international film festivals support Latin American films through their sponsorship schemes, such as the Hubert Bals Fund (Rotterdam film festival), the Berlinale World Cinema fund (Berlin Film Festival) and the Cannes Residence Fund (Cannes Film Festival). The Berlin Film Festival, with its preference for political and sociopolitical cinema, has in the recent past bestowed their highest prize, The Golden Bear, to Brazilian, Peruvian or Mexican filmmakers such as Walter Salles (Centro do Brasil, 1998), Claudia Llosa 
(La teta asustada, 2009) and José Padilha, (Tropa de elite, 2008). This certainly helped the directors and their pictures to gain attention in and beyond Europe. Argentine, Chilean or Bolivian productions have participated in various Berlinale competition streams. Filmmakers Daniel Burman (El abrazo partido, El rey del Once) and Sebastián Lelio (Gloria, Una mujer fantástica) have become darlings at the Berlin Film Festival.

International film festivals are venues that lend prestige to and boost the reputations of new directors, and which mark their entry to the international film scene and facilitate their receiving support from other funding sources. Within the last few decades, "global auteurs" have emerged, as Ignacio Sánchez Prado calls them. As he notes, the successes of celebrity Mexican filmmakers Guillermo del Toro, Alejandro González Iñarritu, Alfonso Cuarón and lately, Carlos Reygadas, in many and diverse international film circuits have much to do with their ability to make films that negotiate universal themes while maintaining a preoccupation with distinctly national themes (Sánchez Prado 2014b, 157-58).

In the highly competitive field of filmmaking, for the majority of younger, talented and aspiring Latin American filmmakers, it is a difficult and lengthy endeavor to obtain the resources for a proposed film project without an already established professional network and, moreover, a good sense of business. The filmmaking budget is usually a piecemeal affair, consisting of money from public, private and a number of foreign sources. Pressured by the business model in place, the vast majority of Latin American films are being made as international coproductions. Hence, while Latin American cinema is praised as a post-national or emancipated cinema, its transnational character is in fact a product of neoliberal demands. ${ }^{3}$ According to Paul Schroeder Rodriguez, most Latin American films are market products "that facilitate the films' marketing to international audiences and help satisfy the differing economic and political interests of the coproducing parties" $(2016,247)$. Randall Halle warns us that such coproductions are being made for European audiences: "Under the guise of authentic images, the films establish a textual screen that prevents apprehension of the complexly lived reality of people in not-to-distant parts of the world" $(2010,314)$. Funding conditions establish neoliberal forms of censorship. Production companies and business partners might dictate from the scriptwriting stages onwards what a film should look like; exerting their influence over themes and aesthetics, and facilitate clichéd and exoticized views of Latin American landscapes, cultures and people. 
Yet, transnational ventures can also create opportunities to challenge stereotypes and widen audience bases. Bianka Ballina notes that coproduced films allow for an elasticity of discourses. Aside from satisfying a global group of spectators, they may contain elements that require a "shared cultural and historical experience" between local audiences, which make such films all the more meaningful on national terrain (Ballina 2017, 210). Smaller national cinemas, such as that of Uruguay, survive only if coproductions strike a balance between acceptance of a local audience and appeal to international spectators (Rocha 2017). Coproduced films most often secure their circulation in several countries, increasing the potential of their exposure to different communities and groups.

If it is subordinated to the ubiquitous command of the market, from which position can Latin American film speak? Film scholar Joanna Page enquires with reference to Argentine film: "What meanings, and conflicts between meanings, are generated by mounting a critique of neoliberalism within a medium produced and distributed in the context of a world market dominated by neoliberal policies and practices?" $(2009,4)$. David Hesmondhalgh reminds us that texts produced and circulated in the cultural industries "tend to orientate their audiences towards ways of thinking that do not coincide with the interests of capitalism or of structured domination by men over women or institutional racism" $(2013,5)$. In other words, within the spaces of commodification, there are loopholes and officially sanctioned places which invite criticism and resistance to the neoliberal machinery. The ever-expanding funding scape offers opportunities to get film projects off the ground. Crowdfunding is a particularly effective way to promote film projects, tap into additional financial resources and reach audiences worldwide (see also Chapter 9: Carolina Rocha's case study). Some sponsorship schemes are specifically targeted to support the projects of young, first-time or female filmmakers. Julia Solomonoff, Icíar Bollaín, Claudia Llosa, Alicia Scherson, María Ramos, Paz Fábrega, Anna Muylaert, Mariana Chenillo or Laura Amelia Guzmán are just a few names belonging to a younger generation of filmmakers who strengthen Latin American cinema with uncomfortable views on social and economic tendencies and conflicts. Female filmmakers observe and comment on neoliberal sensibilities and their historic and social dimensions in distinctive ways. Among them, Lucrecia Martel is perhaps the most provocative and articulate director. According to Patricia White, Martel's uncompromising films prevent "easy cross-cultural consumption of her explorations of class, race, and history" (White 2015, 187). 
In 2003, scholar Marvin d'Lugo articulated his hope for Latin American film authors to see filmmaking as a chance for meaningful collaborations, "through collaborative practices that have as their ultimate goal not the erasure of the local but a meaningful relocation of it in the global community" (2003, 122). Within current communal, cross-cultural, regional North-South collaborations, frameworks and agreements, great responsibility rests with Latin American filmmakers themselves to use their voice, their talent and intuition, and despite economic pressures, preserve their national, cultural and artistic integrity and to carve spaces and acceptance for their work and that of their peers.

\section{Neoliberal Sentiments Reflected, RESENTED AND RESISTED}

The term resistance echoes a longer history of filmmaking in Latin America. In regional offshoots from the 1950 s and as a continental project known as New Latin American Cinema ten years later, it was a socially committed filmmaking with a documentary and experimental character that sharply criticized colonialism, political hegemony and economic dependence on the First World. Filmmakers wanted to inform, educate and emancipate Latin American audiences. Pronounced class differences, cultural domination, and racial and ethnic inequalities remain pressing problems. And in the claws of a market-oriented system and policy making, there are additional concerns that plague contemporary Latin American societies these days, such as environmental disasters, ever widening income gaps, deindustrialization processes and the disappearance of public spaces (see Amann and Baer 2002). Jameson maintains that "We cannot return to aesthetic practices elaborated on the basis of historical situations and dilemmas which are no longer ours" (1991, 50). He continues, arguing that "political art ... will have to find a mode of representing this world space of multinational capital —in which we may begin to grasp our positioning as individual and collective subjects and regain capacity to act and struggle - a global cognitive mapping, on a social and a spatial scale" (54). Contemporary Latin American film, in order to demonstrate, report on and resist neoliberal ideology, has to respond to film-literate audiences and address subjectivities and sensibilities that have long since been shaped by neoliberal economic and political realities. ${ }^{4}$

Films magnify the ways in which contemporary Latin American communities and societies have been affected by neoliberalism: observing 
how we live and feel, as individuals, as citizens and human beings, what our private relations and social networks are and our notions of private and public spheres. Neoliberal philosophy has changed relations and conditions especially in the workplace. The logic of competition produced a particular subjectivity which turned citizens into alert, mobile, competitive and isolated owners of their professional careers (Read 2009, 30 ). The availability and acquisition of goods and services makes citizens into consumers. ${ }^{5}$ Privately educated, technology-savvy, able to make money, earn money, spend money, the inexorable trend towards individualization is fed to new generations that value material goods and believe that they are able to steer their own destiny (Araujo 2017), while replacing attention for and solidarity with other members of the communityweakening bonds between social classes.

Individualistic trends have modified perceptions and shifted interests of filmmakers. An "identity-based first-person cinema" (Lazzara 2016, 24) tends to smaller stories, about single characters, or about mundane, everyday issues related to isolated characters from middle and upper-middle classes, Schroeder Rodriguez calls this a melorealist cinema that has an "intimist, realist and ultimately conformist" character (2016, 250). An inclination towards private spaces as conflict territory and an emphasis on the microcosmos of the family can be observed in contemporary Chilean films such as in La sagrada familia (Sebastián Lelio, 2005), La nana (Sebastián Silva, 2009), Las turistas (Alicia Scherson, 2009), the intimate pictures of Matias Bize's En la cama (2005) and La vida de los peces (2010). Roberto Trejo remarks on the kind of protagonists that populate Chilean screens:

The hero or heroine in Chilean cinema is an individualist self-centered and narcissist character, amoral personalities who are born into a consumerist society. [There is] the ingenuous, hedonistic search for satisfaction, pleasure and desire. [These are] dematerialized individuals ... who do not live in any recognizable place, [who are] dislocated, and psychologically immature. $(2014,25)^{6}$

The tendency in Latin American documentary and feature film to narrate experiences from a personal perspective is equal to deploying the "bourgeois I," as Antonio Gómez calls it so poignantly, which reflects developments towards individualism and self-fulfillment under a neoliberal 
aegis $(2016,65)$. In fiction film, the emphasis on individual characters in middle-class milieus can be seen in affective formal properties, emotional modes of address and a preference for genres. The melodrama, as Sanchez-Prado notes, relates to conventions and heterosexual norms of the middle class, is often set in affluent neighborhoods or indoor settings that forego any social conflicts or pressures, portraying aspirations and anxieties of highly educated and career-aspiring freelance-working protagonists, and celebrating the fragility of current labor agreements as virtue and freedom. The romantic comedy is another genre form "made available by neoliberalism ... which provided middle and upper class audiences with the fiction of a central role in a new, modern Mexico and which systematically excludes lower classes from its imagination of the social" (Sanchez Prado 2014a, 4). Besides, the increasing number of genre productions in commercial Latin American cinema are linked to the need to comprehend and market Latin American culture within universal genre conventions $(2014 \mathrm{~b}, 156-61)$.

Then again, Latin American films of the last decades interrogate the conditions that have structured social life and created class boundaries, and portray those outside of the "golden club" of creative employment options and consumerist pleasures. Films such as Pizza, birra, faso (Adrián Caetano, 1997) or El bonaerense (Pablo Trapero, 2002), represent what was later termed New Argentine Cinema-a low-budget style of filmmaking that was born from a lack of resources. In films as early as Nueve reinas (Fabián Bielinsky, 2000), anticipating and documenting the 2001 economic crisis in Argentina, money is a subject which reflects their status as market commodity (Page 2009, 5). Money is a concern for and features in current films throughout Latin America. O dolares de arena (Laura Amelia Guzmán and Israel Cárdenas, 2014), Magallanes (Salvador del Solar, 2015), La deuda (Barney Elliott, 2015), Soledad (Jorge Thielen Armand, 2017), Tambien la lluvia (Icíar Bollaín, 2010), Relatos salvajes (Damián Szifron, 2015) and El soñador (Adrián Saba, 2014) are narratives set in and between national, cultural and historical contexts, which in suspenseful atmospheres deal with uneven financial deals, scams, heists, or money laundering. Schroeder Rodriguez notes that the uncertainties that characters face, are being represented in the trope of suspense: "Suspense, with its focus on the immediate, [which] is especially well suited to exploring the political, economic, and social precariousness of the present historical moment"(2016, 289). 
Genres such as the thriller, western or comedy frame the above mentioned and other Latin American films and enable their commodification. But filmmakers also utilize their subversive potential to capture specifically Latin American experiences and sensibilities, reflecting on and criticizing neoliberal ideology, its middle-class social conventions and moral regimes. ${ }^{7}$ James Scorer examines Un oso rojo (Adrián Caetano, 2002) within conventions of an urban western that unfolds in contemporary Buenos Aires as a socially fragmented urban space populated by urban cowboys with an ambivalent moral code of justice (2010). ${ }^{8}$ The road movie is a critical genre that has found increasing scholarly interest. While internationally successful feature films such as $\Upsilon$ tu mamá también and Diarios de motocicleta (Walter Salles, 2004) express a utopia of freedom and mobility, border crossing and coming of age stories, other Latin American road movies are transformative journeys of emigration, exile and displacement that subvert tropes of mobility. In the introduction to their volume, The Latin American Road Movie, Verónica Garibotto and Jorge Perez note: "Whether celebrating, resisting, or conforming to neoliberal values, they [road movies] have staged a regional landscape that contrasts with the neoliberal discourse of progress, wealth, and success" $(2016,10) .{ }^{9}$ A number of films made in Central American countries such as Guatemala, Honduras and Mexico, like Sin nombre (Cary Joji Fukunaga, 2009) or La jaula de oro (Diego Quemada-Díez, 2013), are stories of crossing the border between Mexico and the United States, documenting a desire for a better life in the wealthier North, which often end in disillusionment, imprisonment and death. These films use an affective register as aesthetic means to articulate individual experiences and criticism of neoliberalism (Podalsky 2011). Rosalind Galt, analyzing the film Tan de repente (2002) by Diego Lerman, notes that a form of slowness deployed in its narrative and aesthetic structure is a refusal of a world order determined by productivity and efficacy (2013). Important interventions in the current Latin American film scape in which affective affinities link aesthetics and politics, such as El Club (Pablo Larraín, 2015), La Teta Asustada or Magallanes, expose past violence resurfacing as repressed memories in the present, of meetings between victims and perpetrators pressured by current-day economic realities and financial pressures.

To conclude, contemporary Latin American films, while inextricably connected with global neoliberal circuits of production, distribution and 
North-South power relations. Martínez-Exposíto argues that También la lluvia aligns conflictive issues of decolonization and neoliberalism and is a text that contests "prevalent modes of neoliberal film production and consumption in Latin America." Rosana Diaz-Zambrana takes the Peruvian films Octubre (Diego Vega and Daniel Vega, 2010) and El limpiador (Adrián Saba, 2013) as a lens to observe fractured and distorted personal relationships, an inability of the male protagonists of these features to form social bonds and handle memories of a traumatic past, as configurations of the neoliberal society in Peru. The dystopic urban spaces that establish the mis-en-scénes to these films align with spatial trajectories in Maria Mercedes Vázquez Vázquez's chapter. Vázquez adds a fresh perspective to the idea that Latin American film is increasingly interested in the realm of the middle classes. With a cross-cultural reading of the Mexican Post Tenebras Lux (Carlos Reygadas, 2012) and the Brazilian Que horas ela volta? (Anna Muylaert, 2015), the scholar finds this tendency deployed in the use of cinematic spaces and linked to the middle-class background of the filmmakers themselves. Niamh Thornton also examines filmmaking linked to filmmakers as neoliberal subjects. With reference to the Mexican feature Paraiso ¿Cuánto pesa el amor? (Mariana Chenillo 2013), Thornton observes a striving for the perfect Latina body on and off screen, a stereotype that female director and lead actress feel exposed to, pressured by neoliberal demands.

The chapters of Part II, "Neoliberal Film Policies and the Global Market," discuss demands of global players and their impact on local film industries and revisit Latin American filmmaking in response to local, neoliberal-economic policies and regulations. This part starts with a contribution by Jacobo Asse Dayan who examines the state of the Mexican film industry and its morphing to neoliberal ideology. His findings frame an analysis of Güeros (Alonso Ruizpalacios, 2014), a film that bridges the 1999 student protests with the 1968 Tlatelolco massacre. He comes to an interesting finding: "The 1960s youth movement's individualistic spirit played into the hands of neoliberalism, and, ironically, today's paralysis might be, in some small part, the result of yesterday's rebellion." Sarah Barrow emphasizes the role of the producer as an arbitrator for filmmakers in a highly competitive funding environment. She studies the case of the Peruvian producer Enid "Pinky" Campos. As one of the few women in the field, focused on socially committed film projects, Campos's work resonates with that of enigmatic figures such as Lita Stantic. Barrow highlights the changed profile of a young generation of 
filmmakers who needs soft power skills and market experience to negotiate the commercial aspects of filmmaking. Film anthropologist María Paz Peirano discusses Pablo Larraín's No (2012)—a film about the advertising campaign that facilitated the 1988 Chilean referendum to end Pinochet's regime - as a catalyst for a hot political debate about the installment of economic neoliberalism during the Pinochet dictatorship. Peirano's reception analyses reveal controversies about the film which are a demonstration of the complex and contradictory relationship of the Chilean film industry with neoliberalism. Carolina Rocha's research into crowdfunding shows that filmmakers can benefit from the neoliberal film market without surrendering their visions. She analyzes the crowdfunding initiatives of three recent films: The Firefly (Ana María Hermida 2013), Dirty Hands (Joseph Wladytka 2015) and An Unknown Country: the Jewish Exiles of Ecuador (Eva Zelig 2015). Rocha highlights these ventures as a way to tap into financial resources worldwide, and an effective way of establishing a local and global film audience about themes that are relevant in Colombia and Ecuador. Andrea Morán and Miguel Fernández Labayen contribute to this volume with a case study about the Argentine film industry. They illustrate how transformations of the film sector from analogue to digital extend theatrical exhibition space(s) and revenues for Hollywood products at the expense of national film. The scholars discuss measures taken by the Argentine state with the aim of using digital technologies for the benefit of the local industry, some of which are controversial but are shown to be moderately effective.

Part Three, "Defiant Actors and Marginal Spaces," is concerned with examples of contemporary film and filmmaking practices that use innovative approaches to tackle geographical, cultural and social margins defined by neoliberal ideology. Walescka Pino-Ojeda's essay about Pablo Larraín highlights the vital importance of Larraín's work as neoliberal critique in the Chilean social context. Pino-Ojeda examines the narrative and aesthetic character of Larraín's films as "cynically affective" cinematic approaches. On the basis of her readings of Tony Manero (2008), Post Mortem (2010), No (2012) and Neruda (2016), the scholar finds that Larraín's films contain neoliberal and political criticism in commercial formats; they have an elusive quality that is somewhere between reflecting, utilizing and criticizing the commercial character of contemporary cinema. Similarly using and productively "abusing" filmmaking conditions and regulations in Colombia that promote film as a market product, Carlos de Oro discusses Alias Maria (José Rugeles 2015). The 
film benefitted from the neoliberal system of production and exhibition to promote its subject. Made in a participatory mode with children and adolescents who have gone through experiences of warfare in Colombia, the film forms part of other activities that the film crew organizes with affected groups and communities in remote areas. Claudia Sandberg, concerned with filmmaking ventures in rural spaces, analyzes the films of Argentine director Maximiliano Schonfeld with and about the Volga German community in Entre Ríos. Given that only one-fifth of the Latin American population still live in villages and small towns, it is often overlooked that neoliberalism has majorly affected rurally based citizens and agricultural communities. Sandberg discusses Schonfeld's Esnorquel (2006), Entreluces (2006) and Germania (2012) as comments about a people that has been affected by consumer culture and monopolizing tendencies in the agricultural sector. Andrea Molfetta's chapter concludes this volume. She examines forms, themes and organizational structures of two communal, semi-autonomous filmmaking networks which are active in the outer suburbs of Buenos Aires. Molfetta reminds us of the vulnerability of these initiatives in a volatile political environment and changing sense of national culture in Argentina. With these neighborhood-based enterprises of film making and film viewing that happen in the spirit of sharing resources and exchange of experiences, social peripheries are regained as culturally vibrant centers. Here, cinema emerges as form of local expression and social empowerment, which is in essence what cinematic resistance to neoliberalism is all about.

\section{Notes}

1. Cacilda Rêgo and Carolina Rocha discuss filmmaking trends from 1995 onwards, when both Argentina and Brazil took legislative measures and went new economic pathways which had an impact on filmmaking in both countries (2011).

2. See Ibermedia news item on the following link: http://www. programaibermedia.com/nuestras-noticias/guatemala-reingresa-al-programa-ibermedia-y-anuncia-un-programa-de-fomento-a-la-realizacion-cinematografica, accessed August 23, 2017.

3. See for more positive accounts of the transnational and market-oriented nature of Latin American Cinema Deborah Shaw (2007), Anne Marie Stock (2006), and Luisela Alvaray (2008). Joanna Page (2009), Rosalind Galt (2013), and Gerd Gemuenden (2017) are critical about these developments. 
4. Claudia Sandberg's reception study illustrates the lack of and sensibility of a current, young spectatorship in Chile towards ideas raised in progressive film material from the 1970s and 1980s (2017).

5. See García Canclíni's lucid discussion of consumption and citizenship in his influential work, Consumers and Citizens. Globalization and Multicultural Conflicts (2001).

6. The original quote reads: El personaje individualista, autocentrado y narcisista es "héroe" o la "heroína" del cine chileno. Personajes amorales que se construyen desde la sociedad de consume y la simple búsqueda hedonista de la satisfacción del placer y el deseo. Individuos desmaterializados, abstractos, que viven en ninguna parte reconocible, deslocalizados y psicológicamente infantiles.

7. See Barbara Klinger (1984) about the potential of genre film as progressive texts and ideological criticism in relation to Hollywood cinema. More recently, Jonathan Goldberg (2016) added to these ideas a book-length account about the progressive potential of the melodrama.

8. See Rocha's "Caballos salvajes and its critique of neoliberal culture," for a reading of the Western genre in relation to the film Caballos salvajes (Marcelo Piñeyro, 1995) in the context of Argentine neoliberal policies under Menem's government (2007).

9. A number of current publications deal with the Latin American road movie, such as Natalia Pinazza (2014) and Nadia Lie (2017).

\section{Works Cited}

Alvaray, Luisela. 2008. "National, Regional, and Global: New Waves of Latin American Cinema." Cinema Journal 47 (3): 48-65.

Amann, Edmund, and Werner Baer. 2002. "Neoliberalism and Its Consequences in Brazil." Journal of Latin American Studies 34 (4): 945-59.

Arantes, Joé Tadeu. 2017. "Globalization Concentrated Movie Exhibition Market in Latin America.” Agência FAPESP, January 27, 2017. http://agencia.fapesp.br/globalization_concentrated_movie_exhibition_market_in_latin_ america/22598/.

Araujo, Kathya. 2017. "Sujeto y neoliberalismo en Chile: rechazos y apegos." Nuevo Mundo Mundos Nuevos. http://nuevomundo.revues.org/70649.

Ballina, Bianka. 2017. "Juan of the Dead: Anxious Consumption and Zombie Cinema in Cuba." Studies in Spanish \& Latin American Cinema 14 (2): 193-213. Belém Lopes, Dawisson. 2017. "Why is Neoliberalism Back in Latin America?" Aljazeera, July 15, 2017. http://www.aljazeera.com/indepth/opinion/ 2017/07/neoliberalism-latin-america-170711085354385.html.

Cannon, Barry. 2016. The Right in Latin America. Elite Power, Hegemony and the Struggle for the State. New York and London: Routledge. 
Davis, Robert E. 2006. "The Instantaneous Worldwide Release: Coming Soon, to Everyone, Everywhere." In Transnational Cinema: The Film Reader, edited by Elizabeth Ezra and Terry Rowden, 73-80. London and New York: Routledge.

De Luca, Tiago. 2014. Realism of the Senses in World Cinema: The Experience of Physical Reality. London: I.B. Tauris.

D'Lugo, Marvin. 2003. "Authorship, Globalization and the New Identity of Latin American Cinema. From the Mexican 'ranchera' to Argentinian 'Exile'." In Rethinking Third Cinema, edited by Anthony R. Guneratne and Wimal Dissanayake, 103-25. New York and London: Routledge.

Falicov, Tamara. 2013. "Ibero-Latin American Co-Productions: Transnational Cinema, Spain's Public Venture or Both?" In Contemporary Hispanic Cinema. Interrogating the Transnational in Spanish and Latin American Film, edited by Stephanie Dennison, 67-88. Croydon: Tamesis.

Galt, Rosalind. 2013. "Default Cinema: Queering Economic Crisis in Argentina and Beyond." Screen 54 (1): 62-81.

García Canclini, Néstor. 1995. Hybrid Cultures. Translated by Christopher L. Chiappari and Soliva L. López. Minneapolis: University of Minnesota Press.

García Canclini, Néstor. 2001. Consumers and Citizens. Globalization and Multicultural Conflicts. Translated by George Yúdice. Minneapolis, MN and London: University of Minnesota Press.

Garibotto, Verónica, and Jorge Pérez. 2016. "Introduction. Reconfiguring Precarious Landscapes: The Road Movie in Latin America." In The Latin American Road Movie, edited by Verónica Garibotto and Jorge Pérez, 1-28. New York: Palgrave Macmillan.

Gemuenden, Gerd. 2017. "Un nuevo cine peruano? Recent Trends from Lima." Paper given at the Latin American Studies Association Annual Conference, Lima, April 2017

Goldberg, Jonathan. 2016. Melodrama. An Aesthetics of Impossibility. Durham and London: Duke University Press.

Gómez, Antonio. 2016. "Displacing the 'I': Use of the First Person in Recent Argentine Biographical Documentaries." In Latin American Documentary Film in the New Millennium, edited by María Guadalupe Arenillas and Michael J. Lazzara, 63-78. New York: Palgrave Macmillan.

Grugel, Jean, and Pía Riggirozzi. 2012. "Post-neoliberalism in Latin America: Rebuilding and Reclaiming the State After Crisis." Development and Change 43 (1): $1-21$.

Halle, Randall. 2010. "Offering Tales They Want to Hear: Transnational European Film Funding as Neo-orientalism." In Global Art Cinema. New Theories and Histories, edited by Rosalind Galt and Karl Schoonover, 303-19. New York: Oxford University Press.

Harvey, David. 2008. A Brief History of Neoliberalism. Oxford: Oxford University Press. 
Hesmondhalgh, David. 2013. The Cultural Industries. 3rd ed. London: Sage. Jameson, Frederic. 1991. Postmodernism, Or, The Cultural Logic of Late Capitalism, Durham: Duke University Press.

Kapur, Jyotsna, and Keith B. Wagner. 2011. "Introduction. Neoliberalism and Global Cinema: Subjectivities, Publics, and New Forms of Resistance." In Neoliberalism and Global Cinemas. Capital, Culture, and Marxist Critique, edited by Jyotsna Kapur and Keith B. Wagner, 1-16. London: Routledge.

Klinger, Barbara. 1984. “'Cinema/Ideology/Criticism' Revisited: The Progressive Text." Screen 25 (1): 30-44.

Lazzara, Michael J. 2016. "What Remains of Third Cinema." In Latin American Documentary Film in the New Millennium, edited by María Guadalupe Arenillas and Michael J. Lazzara, 23-42. New York: Palgrave Macmillan.

Lie, Nadia. 2017. The Latin American (Counter-) Road Movie and Ambivalent Modernity. New York: Palgrave Macmillan.

MacDonald, Laura, and Arne Ruckert. 2009. "Post-neoliberalism in the Americas: An Introduction." In Post-neoliberalism in the Americas, edited by Laura MacDonald and Arne Ruckert, 1-20. London and New York: Palgrave Macmillan.

Mazierska, Ewa. 2018. "Introduction." In Contemporary Cinema and Neoliberal Ideology, edited by Ewa Mazierska and Lars Kristensen, 1-22. New York: Routledge.

McChesney, Robert W. 2001. "Global Media, Neoliberalism, and Imperialism." Monthly Review 52 (10): 1-19.

Page, Joanna. 2009. Crisis and Capitalism in Contemporary Argentina Cinema. Durham and London: Duke University Press.

Picciau, Kevin. 2011. "Cinemark Strengthens Its Position in South America." Ina Global, November 7, 2011. http://www.inaglobal.fr/en/cinema/ article/cinemark-strengthens-its-position-south-america.

Pinazza, Natalia. 2014. Journeys in Argentine and Brazilian Cinema. Road Films in a Global Era. New York: Palgrave Macmillan.

Podalsky, Laura. 2011. The Politics of Affect and Emotion in Contemporary Latin American Cinema: Argentina, Brazil, Cuba, and Mexico. Basingstoke: Palgrave Macmillan.

Read, Jason. 2009. "A Genealogy of Homo-Economicus: Neoliberalism and the Production of Subjectivity." Foucault Studies 6: 25-36.

Rêgo, Cacilda, and Carolina Rocha. 2011. New Trends in Argentine and Brazilian Cinema. Bristol: Intellect.

Risner, Jonathan. 2016. "How I Learned To Stop Worrying and Grudgingly Accept Product Placement: Nicolás López, Chilewood and Criteria for a Neoliberal Cinema." Journal of Latin American Cultural Studies 25 (4): 597-612.

Roberts, Kenneth M. 2009. "Beyond Neoliberalism: Popular Responses to Social Change in Latin America." In Beyond Neoliberalism in Latin America? Societies and Politics at the Crossroads, edited by John Burdick, Philip Oxhorn, and Kenneth M. Roberts, 1-16. New York: Palgrave Macmillan. 
Rocha, Carolina. 2007. "Caballos Salvajes and its Critique of Neoliberal Culture." Studies in Latin American Popular Culture 26: 167-77.

Rocha, Carolina. 2011. "Contemporary Argentine Cinema during Neoliberalism." In New Trends in Argentine and Brazilian Cinema, edited by Cacilda Rêgo and Carolina Rocha, 17-34. Bristol: Intellect.

Rocha, Carolina. 2017. "Developing a National Cinema through Co-productions", Paper Given at the Latin American Studies Annual Conference, Lima, April 2017.

Sánchez Prado, Ignacio M. 2014a. "Regimes of Affect: Love and Class in Mexican Neoliberal Cinema." Journal of Popular Romance Studies 4 (1): 1-19.

Sánchez Prado, Ignacio M. 2014b. Screening Neoliberalism. Transforming Mexican Cinema 1988-2012. Nashville: Vanderbuilt University Press.

Sandberg, Claudia. 2017. "Not Like the Stories I am Used to': East German Film as Cinematic Memory in Contemporary Chile." Journal of Latin American Cultural Studies 26 (4): 553-69.

Schroeder Rodriguez, Paul. 2016. A Comparative History of Latin American Cinema. Berkeley: University of California Press.

Scorer, James. 2010. "Once Upon a Time in Buenos Aires: Vengeance, Community and the Urban Western." Journal of Latin American Cultural Studies 19 (2): 141-54.

Shaw, Deborah, ed. 2007. Contemporary Latin American Cinema: Breaking Into the Global Market. Maryland: Rowman \& Littlefield.

Simis, Anita. 2015. "Economía política do cinema: a exibição cinematográfica na Argentina, Brasil e México." Versión - Estudios de Comunicación y Política 36: $54-75$.

Skármeta, Antonio. 1997. "Europe. An Indispensable Link in the Production and Circulation of Latin American Cinema." In New Latin American Cinema. Volume One. Theory Practices and Transcontinental Articulations, edited by Michael T. Martin, 263-69. Detroit: Wayne University Press.

Stock, Ann Marie. 2006. "Migrancy and the Latin American Cinemascape: Towards a Post-national Critical Praxis." In Transnational Cinema. The Film Reader, edited by Elizabeth Ezra and Terry Rowden, 157-66. London and New York: Routledge.

Trejo, Roberto. 2014. "Cambios culturales, imaginarios colectivos y cine chileno actual." In Audiovisual y politica, edited by Claudia Barril, Pablo Corro, and José M. Santa Cruz G., 15-28. Santiago de Chile: Editorial Arcis.

Venugopal, Rajesh. 2015. "Neoliberalism as Concept." Economy and Society 44 (2): 165-87.

White, Patricia. 2015. Women's Cinema, World Cinema. Durham and London: Duke University Press. 